\title{
HIGH CURRENT SUPERCONDUCTORS FOR TOKAMAK TOROIDAL FIELD COILS ${ }^{*}$ \\ W. A. Fietz
}

Oak Ridge National Laboratory

Oak Ridge, Tennessee 37830

For Presentation

\author{
Applied Superconductivity Conference \\ Stanford, California \\ August 17-20, 1976
}

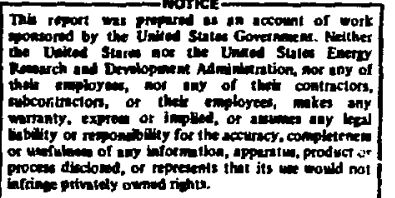

By acceptance of this article, the publisher or recipient acknowledgcs the U.S. Government's right to retain a non - exclusive, royaliy - Irae liconce in and to any copyright covering the articils.

NOTICB

PORTIONS OF THIS REPORT ARE ILLEGIBLE. It

has been reproduced from the best available copy to permit the broadest possible availability.

* Research sponsored by the Energy Research and Development Administration under contract with Union Carbide Corporation. 


\section{ABSTRACT}

Conducto $\mathrm{s}$ rated at $10,000 \mathrm{~A}$ for $8 \mathrm{~T}$ and $4.2 \mathrm{~K}$ are being purchased for the first large coll segment teste at ORNL. Requirements for these conductors, in addition to the high current rating, are low pulse losses, cryostatic stability, and acceptable mechanical properties. The condtctors are required to have losses less than $0.4 \mathrm{~W} / \mathrm{a}$ under pulsed fields of $0.5 \mathrm{~T}$ with a rime time of 1 sec in an ambient 8-T field. Nethods of calculating these losses and techniques for verifying the perforwance by direct measurement are discussed. Conductors stabilized by two different cooling methods, pool bolling and forced hellum flow, have been proposed. Analysis of these conductors $1 \mathrm{~s}$ presented and - proposed definition and test of stability is discussed. Mechanical property requirements, tensile and compressive, are defined and test methods are discussed.

\section{INTRODUCTION}

Although the designs proposed for supercondurting tokamak machines differ videly on many technical points, there is general agreement on one item: the operating current in the field colls will be higher than in any of the presently operating superconducting devices for the magnetic flelds involved. Experinental devices for the near future are expected to operate at 10,000 to $20,000 \mathrm{~A}$ in peak fields of $8 \mathrm{~T}$, while more anbitious projects farther down the road may require conductors rated up to $80,000 \mathrm{~A}$, possibly at even higher magnetic flelds.

Nevertheless, operating current is only one of the requirements of the tokamak field coil conductor. A atudy of the proposed operation of the machines leads to the selection of five basic conductor specification areas. These are operating current, pulsed field loss, stab1lity, mechanical properties, and insulation. The conductor must neet the requirements of sach category and still be of a design that can be readily and econoulcally fabricated.

The first tep toward the developsent of these conductors at ORNL w111 be taken by the large coll segrent tests. Conductors for these tests have been specifled and requests for quotations have been "1ssued. These specifications are briefly sumarized in Table it along with future projections. These bases for these opecifications are reviewed and four potential conductors are analyzed in the balance of this paper.

\section{THE SPECIFICATIONS}

\section{Operating Current}

In the toroldal field colls, the desire for high currents is based on the need to 11mit voltages during charging and discharging the coil, on the fact that a larger, more robust conductor uili usually result in a atiffer winding, and on a need to reduce the labor of coil windiag. In the resulting trade-off against h1gher losses in the current leads, a current of a $f(x)$ tens of thousands of aperes has usually been

Kanuscript recelved August 17, 1976.

"Research sponsored by the Energy Research and Development Adainiatration under contract with Union Carbide Corporation.

${ }^{\dagger}$ Superconducting Magnet Development Progran, Thernonuclear Division, ORHL, Dak Ridge, Tennessee 37830. enlected for tokanak Jesigns. In order that the large coll segment tests properly stmulate toknisk conductor dealgns, an operating current of $10,000 \mathrm{~A}$ at $8 \mathrm{~T}$ and $4.2 \mathrm{~K}$ was selected. Th1s choice appears to be the anullest value whlch will provide a eignificant increase over present practice and etill be in the operating range of tokanak machines.

\section{Pulned Field Losses}

Although the tokaralk field colls thenselves produce a steady tate angetic field, the plasins is operated Internittently. This operation results in a pulsed magnetic fleld at the field coll conductor. Reference designs for the Oak Ridge Experivental Power Reactor (EPR) predict that pulsed magnetic fields of about 0.5 T with a rise tive on the order of one second will be present at the toroidal field windings with a duty cycle of about 17 . These pulsed fields w11 have one couponent parallel to the conductor and one perpendicular to the conductor in a direction outward from the minor axis of the torold. The orientation of these components 1s shom in Fig. 1. Losses In the conductor as a result of these fields arise fron aeveral sources: eddy currents in the norral conductora, hysteresis losses in the superconductor, and cüpling lossea between fllamente in the conposite. Control of these losses requires proper sizing of the normal metal conponents, an optinu filanent dianeter, and the proper twist pitch of the Individusl conductor strand.

Based on refrigeration requirements, a design value for the totgl average pulse loss from these sources of $12 \mathrm{~W} / \mathrm{m}^{3}$ of conductor at $4.2 \mathrm{~K}$ has been chosen. With the 17 duty cycle, this allows a dissipation of $1200 \mathrm{w} / \mathrm{m}^{3}$ during the pulse. This cholce places a linit on the maximun conductor dimension perpendicular to the pulsed field of about 1 in for a high conductivity matrix superconductor in order to Iimit normal eady current losses. In the conductor designs which follow pulse lose consideration is one of the factor that wost strongly affect conductor design. Losses in composite superconductors have been studied extensively 1,2 and wa be calculated from the relationships shown in Table II.

For the purpose of estimating total loss in a complex conductor each continent it eatculited separately. The sun of these contribution is taken as the total loss ignoring interaction effects. In elewents of the conductor wich contain no superconducting filanents only nornal eddy currente are assumed to contribute to the losses.

Miniwizing the total loss with respect to the parameter $x_{0}$ gives the relationship $\left(8 \mathrm{Br} / \lambda \mathrm{J}_{\mathrm{c}}\right)=$ $x_{0}\left[1-\left(1+x_{0}^{2}\right)^{-1 / 2}\right]$, which defizes the optinu value of $x_{0}$. This value is found to be about 0.35 for the conductors and paraneters considered here, correspondIng to a twlat length of about ten dimeters.

\section{Conductor Stability}

The stablilty requiremere for the toknake toroldal field coils can be oinply stated as, "The superconducting coile wat not quench under any conceivable operatins condition that would not otherwise disable the machine." Hethods of achleving a suitable level of confidence in the superconducting colls are not, however, uniquely defined. Stekley, ${ }^{3}$ Laverick, and Whet tone 10 set forts the basic Ideas of cryostatic atability in bolling liquid hellua. They stated that if all the current: flow in noral betal, 
the surface heat transfer must be high enough to allow the conductor to return autowatically to a superconducting state.

This condition for cryostaric stability can be wet by providing enough stabilizing normal wetal and conductor surface area with direct cooling by bolling liguid hellum. The resulting device has a rather low overall current density, usually around $1000-2000$ $\mathrm{A} / \mathrm{cm}^{2}$, and may be too conservatively designed for tokanak use. Higher current density can be obtained by designing for operation below the mirlmu propagatIng current. 6,7 Devices designed to chese specifications can be operated at an overall current density of $2000-5000 \mathrm{~A} / \mathrm{cm}^{2}$. The main differences between the two criteria for stability are that in the mininum propagating current approach heat transfer along the conductor is taken into account, as are the effects of superconducting properties.

Sources of uncertainty in applying the stabillty criterla to real devices arise mostly in the heat transfer properties. A detalled analysis of the geonetry of the entire device is required to ascertain the surface heat transfer at every point. Since reliable calculations verified by experiment on complex machines are not presentiy avallable, conglderable uncertainty exists in applying stability criceria to real devices.

The uncertainties of heat transfer can be largely avolded in principle by using supercritical singlephase helium cooling. The most effective nethod of using the properties of supercritical hellum, as proposed by Hoenig and Montgomery, 8 is to place the conductor inside a condult and force the fiuld through at a rate of several grams per second. Overall current densities of $5000 \mathrm{~A} / \mathrm{cm}^{2}$ have been demonstrated in systems that can recover from a completely normal condition in the conductor.

To spectfy stability under pool boiling condttions for the conductors presently being purchased, the minimum propagating current calculated by the method of Maddock et al. 6 is used, along with the heat transfer curve of iyons. 9 stabllity for forced flow conductors is evaluated using the method of Dresner. ${ }^{10}$ The question of what sort of heat input the conductor should be expected to resover from has not yet been resolved. He have arbitrarily chosen a pulse which gives a momentary temperature rise of $20 \mathrm{~K}$ in the entire conductor.

\section{Hechanical Properties}

The conductor mot be capable of withatanding mechantcal stresses of three types without adverse effects on device performance. The first of these stresses occurs during the winding and handing of the conductor, presumably at room temperature. The conductor is subfected to bending, twisting, tensile, and compressive forces between the tioe of its manufacture and the completion of winding of the device. Analysis of these stresses uill enable the specification of conductor properties and handiling instructions to ensure that the conductor is not damaged. For NbT1 conductors the handling will probably not piasent a problen, but these specifications will be indiepensable for the application of $\mathrm{Nb}_{3} \mathrm{Sn}$ conductors.

A second crucial stress pertod for the conductor may occur during cooldown of the device. Analysts of che structure w111 be necessary to avold overstressing any of the conductor by differential theral contraction within the device. Theral gradients within che wincing will be limited by proper instrumentation sivis controlled coolling of the device. Requireante for cooldown will be prefared prinr to ordering conductor for large devices to aysesa the effects on conductor design.
Pinally, the conductor aust be designed to withstand the stresses of operating the energized device under any conceivable concltions, Including quench. Although the sabilized conductor makes the posslbility of quench remote, an event auch as loss of coolant aght result in a quench which the conductor wat withstand without dange.

Mechantcal specificutions for the conductor wet therefore be very carefully considered. They will obviously depend on the overall desten of the machine and the anticipated operation. For the first conductors operating under simulated toknank condition, three wechunlcal specification have been selected: longltudinal tensile stress of 18,000 pal, a lateral compressive stress capability of 4000 pal, and a bending dianeter of $0.75 \mathrm{~m}$. Each test $1 \mathrm{e}$ to be performed repeatediy (at least 3 tines) on the insulated conductor without resulting in any phyistcel dange or performance degradation.

\section{Inqulation}

Insulation of tokenak conductors is an area requiring a considerable anount of further atudy and experiaent. The Insulation will probably be the component most susceptible to danage by radiation. In addition, the Insulation wut be abrasion resistant and firmiy adherent to the conductor, and 1ts application must be compatible with the conductor component (e.g. curing temperature).

Because of the lack of sultable criteria, the only specification for Insulation for the latge coll segment tests in a dielectric strength of $250 \mathrm{~V}$ between adjacent turns under operating conditions. Probably the Insulation acheme used in the large coll segant tests will be a compronise systen wuch as an open he11x of epoxy-1mpregnated fiberglass or other ater1al.

\section{COsDuctor DEsIers}

\section{Conductor Types}

Although many different claselfications of conductors are posstble, for this evaluation they are grouped according to the wethod of coolins (pool boiling or forced-f(ow) and according to construction (multristrand or monolithic). Within each of these categories further aubdiviejors wy be ande according to thether the basic elewents are transposed, accordIng to construction of basic elements, GtC. Tour of these variations are presented in some detall in the following sections. These are pool bollins leiloated witlstrand, described in F18. 2 and Table III; pool bolling laninated wonolithic, described in Fis. 3 and Table IV; pool bolling tranoposed wultiatrand, described in F1g. 4 and Table $V$; and forced-flon cabled witistrand, described in Fis. 5 and Table VI.

\section{conctustow}

Wone of the foux conductor types analyzed here appears to present any insurwounteble difficuicles in meting the specifications for a tokmak toroldal fleld coll. The selection of a particular deaign w11 probably depend on manufacturing cost unless some other conductor feature not coverud by these spectfications shuld prove objectionable. Tor example, current distribution in the leninated conductors alght be one such probled. If reststance between elements Is moderately "iow, the conductor would behwe like an untwisted fllamentary auperconductiri vä a srose scale. Insulating the elesents and possibly forcing equal current tharing way be une solucion.

Since the pulsed field losses play such a larte part in deteraining the conductor configuration, it 
would be worthntle to re-ex-mine the conductors undar core relaxed pulsed fleld conieralnts. Hy a comblnetion of cuperconductive and normal metal shiclde te ay be poustble to atcenuate the pulsed field by an order to angnitude. If the result ins conductor can be produced atenificantly wore cheaply, weh a schewe wy be worth considering.

loviet and revirion of the cooductor specticisclows and teat wethode are Inportent parta of the superconducting angnet development protram at osjo. Tt Is hoped that a core experience is obtained the conductor requireaepte can be stated wore conclsaly without mbiguity ad that set of apecific teat procedure: for oveluat Ine the fInal produce will be propered.

\section{RrFances}

1. M. S. Walker, G. A. Hatner, and S. S. Shan, Paper

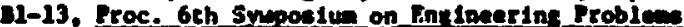
of Fualon Rerearch. 1976.

2. Superconduceins Appilcations Group, Rutherford Laboratory: J. Fhye. D 3i2517, 1970.

3. A. R. Kantroulte and Z.J.J. Stekley, Appl. Thrs. Lect. 6:56, 1965.

4. C. Laverick, Proc. Internet tonal Swoostum on ke= Det Technolo $\%$, P. $360,1965$.

5. C. y. Whetocose, IEEE Trane, wrne 2:307, 1966.

6. B. J. Haddock, C. D. Janes and U. T, Morris. Crropentes 9:261, 1969.

7. J.8.C. H11116m, Fhu. Letc. 19:96, 1965.

8. H. O. Hoents and D. A. Montgonery, 1 EEE Trans. Hern.e. Nag-11:569, 1975.

9. D. N. Lyons, quoted p. 452, Fit. S.7.11, In $\mathrm{H}$. Arechno". Superconductine tarate Sxuece, SpringarVarlag, Ver York, 2973.

10. Lewrence Dreatat, Paper S-1, chls conterence.

TALI: I

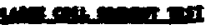

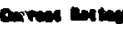

new inem

menters

nomed menteres

Monexten

\section{-1.7.}

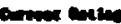

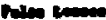

simate

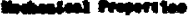

anmexese

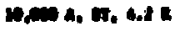

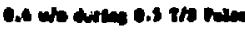

crmente

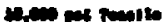
4 ind ind

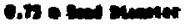

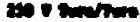

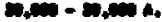

- 125.3 .6

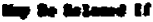

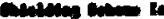
Cunives

erimanate

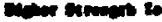
eneminte

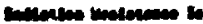
comina

Tare in

Ralationahips for Caicular ins Fules Fiald loes do conpente cosductor:

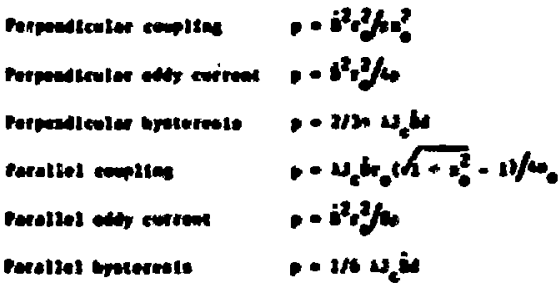

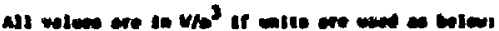

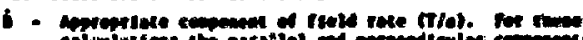

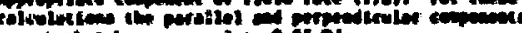

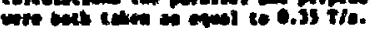

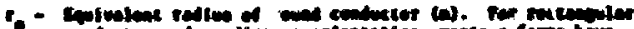

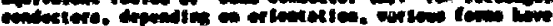
comicto.

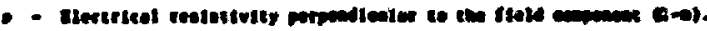

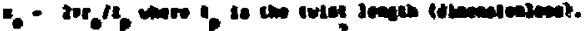

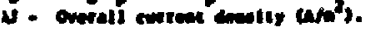

- Micmere decoter (b).

THE II

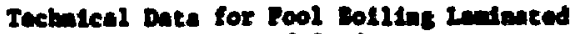
rultefstrond conductor

onrols cuncusens

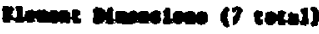

themence core (comper)

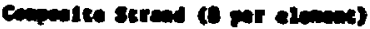

Cuner serand (14 por element)

spectios betwes stemete

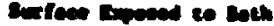

Coved Bertester

mernil Coniveter inoletence

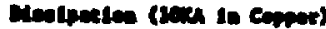

Curnese beatey in neel

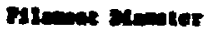

Nilenets ene stren

Cruted curtent

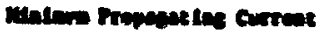

Palew reld tome

Matme ine center

Tax 1

Techaleal Date for Pool Dotuing Landated Howitehte candertor

Comealt ckenalem

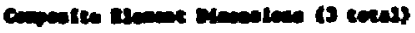

Comer ants (12 tevel)

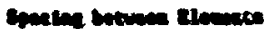

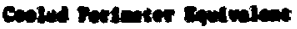

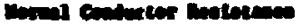

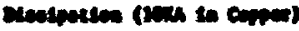

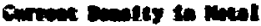

nivent renter

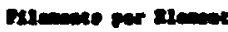

cetetent ortione

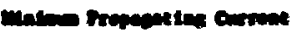

Filoed riste kave

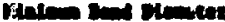

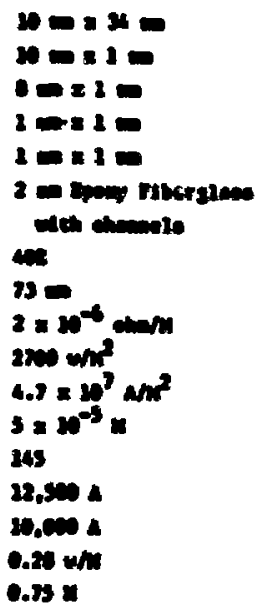
F

돈

c 25

$30 \div 5$

cheresere

at

$3.6=20^{-6}$ ins

sis net

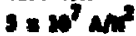

$s=\mathrm{n}^{-5}$

I.

12.

IDen

C.5 $\%$

c.5 1 
TAT: $y$

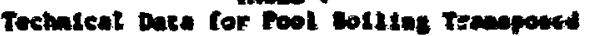
minterend conductor

\section{cmall chemenen}

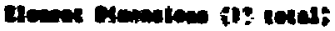

Leome Com (omm)

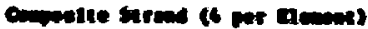

coner tertat is ow thenow)

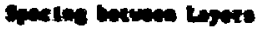

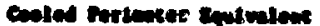

Burell comberter motwienes

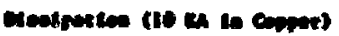

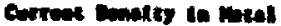

nitenet remet

Mremes on serw

critued burent

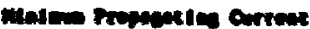

milew phell tase

watos sen monete
$13 \times m=$
$4.50 .45=$
$1.3=8.30$
1.5001 .50
$1.501 .3=$
$2 m$
40
$4.7 \div 10^{-6}$
3ic $\mathrm{an}^{2}$
$0.0=\omega^{2} \omega^{2}$
$8.10^{-5} n$
Iss
12,340
10,6
t.an wh
D.7s $n$

Tule vi

Techateal Date lof poreed Hew cabled Mintetserand Coniwetor

owrall ofmastem

Compertice strom (12) tekall

Cowar seread (24) tetal)

smbece browed te eath

cosed mriteret

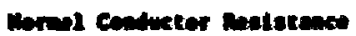

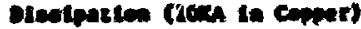

Cucroas condey in weel

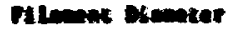

Dilemente per Strend

$3 \div 20$

critied comment

$1.1=d 10$

1.1 .110

a)

50

$1.2 * 10^{-6} \operatorname{com}$

$1.35 m^{2}$

$3.5 \div \mathrm{sin}^{2} \mathrm{wn}^{2}$

$5 \times a^{-5}$

**

12,530 A

10,040 \&

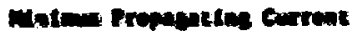

trised rold tea:

-.7. $\mathrm{w}$ /

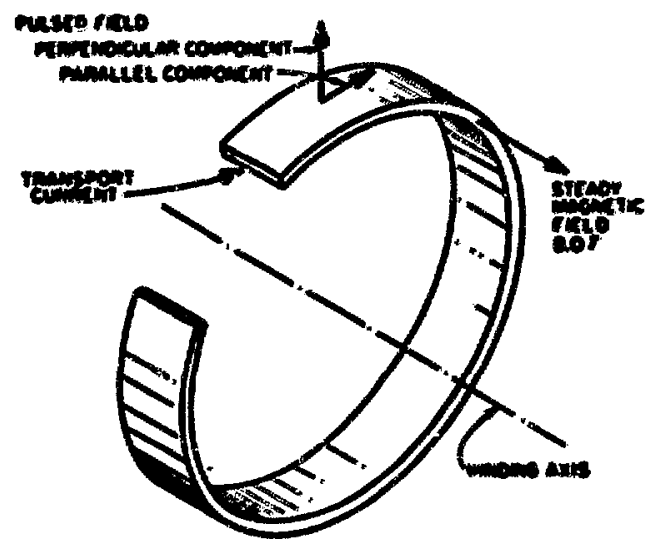

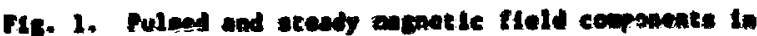
- toknan tuslen renctor.

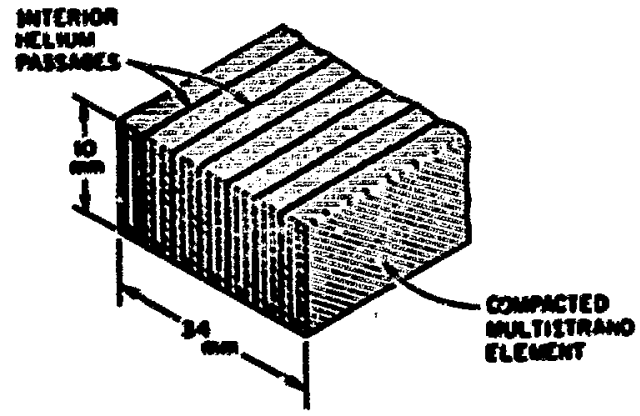

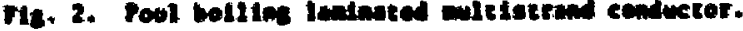

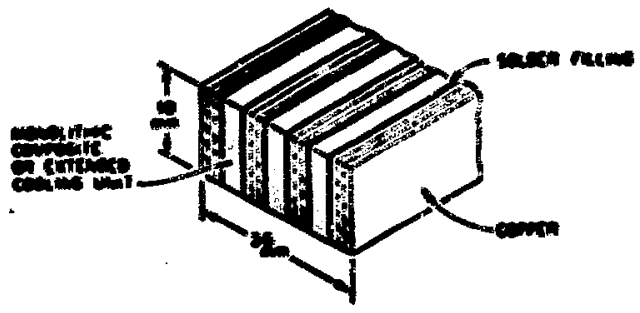

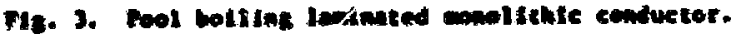

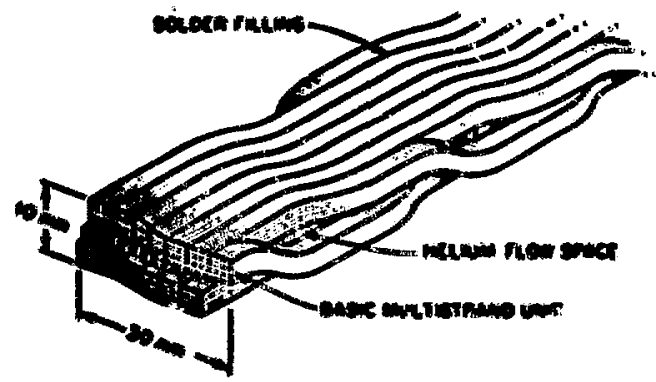

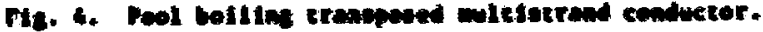

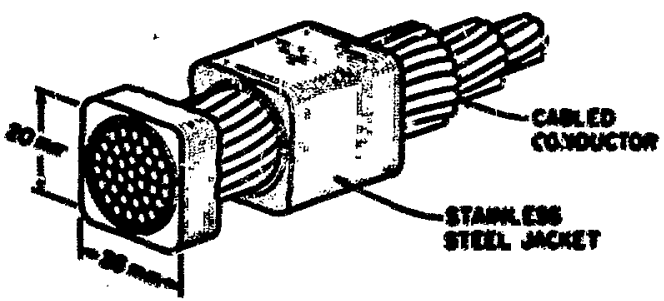

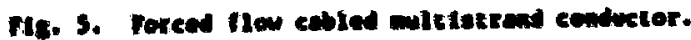

